International Journal of Applied Linguistics \& English Literature

ISSN 2200-3592 (Print), ISSN 2200-3452 (Online)

Vol. 1 No. 7; November 2012 [Special Issue on Applied Linguistics]

\title{
A Socio-Semantic Study of Selected Nicknames Used by Yoruba Brides for In-Laws
}

\author{
Adebola Adebileje \\ Department of English, Redeemer's University \\ P.M.B 3005, Redemption Camp, Ogun State, Nigeria \\ Tel:+2348034904203Ｅ-mail: bolaomolara@yahoo.co.uk
}

Received: 07-10- 2012

doi:10.7575/ijalel.v.1n.7p.180
Accepted: 10-11- 2012

Published: 25-11- 2012

\begin{abstract}
This study aims at describing the socio-semantic characteristics of twelve selected nicknames used by Yoruba brides for their in-laws. The data for the study was collected through observation, structured interview and review of literature. The collected nicknames were described and classified according to Halliday's theory of context in order to get contextual meanings of the selected nicknames. Comparison between lexical and contextual meanings of the nicknames was provided based on the cultural background of Yoruba brides and results revealed that $58 \%$ of selected nicknames coined by brides compliment in-laws, $17 \%$ are derogatory and $25 \%$ assume the dual functions of being compliments and insults. In addition, nicknames' meanings reveal the type of relationship that exists between the bride and her in-laws as the surface meanings of nicknames sometimes may not be the same as the meanings intended by the bride. It is recommended that this culture in Yoruba marriage should be encouraged among modern Yoruba youths who seem to have neglected it.
\end{abstract}

Keywords: Nicknames, Yoruba brides, socio-semantic, Yoruba marriage

\section{Introduction}

The Yoruba culture (beliefs and practices) can be best imagined and appreciated through her marriage patterns and structure. A bride-to-be consciously courts the love and respect of her proposed in-laws to secure her marriage to the groom-to-be. As soon as the wedding is over, she still tries her best to maintain the affable relationship between her and the in-laws. An effective way of achieving this is to be skillful at coining nicknames for her in-laws both young and old. This effort by the bride endears her to the in-laws because of two major reasons: first, it shows that the bride has a good pedigree; second, it is forbidden for a bride to relate with her husband's family members on a first name basis.

A name can be likened to a DNA among the Yoruba because it reveals a lot about the bearer. Yoruba names provide clear specifics which is in marked contrast with the rather anonymity nature of English names. A Yoruba name can identify the individual, his relationship with and position in the family and the society. For instance, "Ogunwale" simply provides the information that the bearer or his predecessor is an Ogun (god of iron) worshipper and has finally come back home for good. In other words, Yoruba names represent circumstances of birth, history, family, religion, or some other equally significant details about the individual bearing the name.

Sowande (1967) succinctly describes naming in Yoruba culture thus:

Yoruba names are therefore much more than mere identification tags, much more than mere "luggage labels"; each has a reason (a) for being just what it is; and (b) for being given to a particular individual. Yoruba names embody circumstances of birth, history, family, religion, or some other equally pertinent facts relevant to that particular individual bearing the name. Yoruba names are, in fact, in most cases contractions of whole sentences (p 39).

This implies that naming a baby or a person depends on the prevalent social conditions in a family at the time the baby is born and the type of virtues the parent desires for the baby. There are circumstantial or preordained names (Oruko Amutorunwa) e.g. Alaba meaning second child born following the birth of twins; names given at birth (Oruko Abiso) e.g. Ige meaning born feet first; names given to babies believed to come back after they have died i.e. born looser (Abiku) e.g. Igbokoyi meaning the forest has rejected this. Pet names (Oriki) e.g. Asake 
International Journal of Applied Linguistics \& English Literature

ISSN 2200-3592 (Print), ISSN 2200-3452 (Online)

Vol. 1 No. 7; November 2012 [Special Issue on Applied Linguistics]

denoting specially selected to be treasured; and nicknames (Inagije) e.g. Adumaadan meaning black and shiny.

Thus, names can have semantic contents and reflect real world knowledge. It is insightful to note that the coding of information into names is based on the lexical, syntactic, semantic and pragmatic rules of the Yoruba language.

\subsection{Nicknames}

The Longman Dictionary of Contemporary English defines nickname as a familiar, invented given name for a person or thing used instead of the actual name of the person or thing. It is a kind of byname that describes a person's characteristics and attributes. In other words, nicknames generally depict an informal and/or humorous characteristic, personality and appearance of a person. A nickname is sometimes considered desirable, symbolising a form of acceptance, but can often be a form of ridicule. Nicknames are usually given to, not picked by the recipient. While some nicknames are derogatory name calls, some others are complimentary. Nicknames may be based on a person's name or various attributes. Attributes upon which a nickname may be based include: lifestyle, mental characteristics, personality, and titles.

As much as the use of nicknames for in-laws is part and parcel of the Yoruba culture as far as marriage is concerned, some other African tribes like the Akans of Ghana, consider the use of nicknames verbal taboos and so do not use them because they cause conflicts. Thus, the use of nicknames involving the description of people's physical structure like complexion, height or size, or a person's behaviour is prohibited.

In the Yoruba culture, especially among the Ijesa tribe, nicknames are prevalent and are actually preferred because they conceal peoples' real names from the evil ones who may want to cast some evil spell on people's real names. Such names as "Adagun-odo" (stagnant river) "Aro-mo-laran" (somebody who wraps babies with velvet material) "Eja-lo-ni-bu" (the fish owns the sea) are nicknames depicting great wealth but have been retained as actual family names.

\subsection{Marriage in the Yoruba Culture}

Marriage in the Yoruba culture is regarded as a rite that establishes the foundation of the family. Unlike contemporary marriages, the Yoruba marriage is seen as a union not only of the two spouses, but a union of the two extended families to which they belong. Marriage is the proof that both spouses are good products and ambassadors of their families and a good reflection of the quality of character of their families. To ensure that the spouses have the required qualities, an elaborate system of regulated activities is put in place to test the genuineness of the spouses' claim of love. This action reiterates the fact that the spouse selection process is a communal affair in the Yoruba culture. Babatunde (1992) presents the following six important steps that lead to the traditional Yoruba marriage.

- The time for seeking a potential spouse (Igba ifojusode);

- The approval of the oracle-divinity (Ifa f'ore); in other words, 'Ifa has spoken well'

- The release of the voice of the young woman (Isihun);

- The request for the young woman's hand in marriage (Itoro);

- The creation of the affinal bond (Idana); and

- The transfer of the wife to the husband's lineage (Igbeyawo).

Traditionally, it is expected that when a young adult male is between twenty three and twenty-eight years of age and a young lady is between eighteen and twenty-five, they should be engaged with potential spouses. At this time, the male is expected to have acquired skills that will allow him to provide for his family. The Yoruba socialization process ensures that the daughter learns, from the age of seven by acting 'little mummy' to her younger siblings. At the time of preparing for marriage, she is already competent in some of the preliminary skills needed to be a wife and mother. This informal education is largely achieved by the bride through keen observation of her mother and other women in her family.

The Yoruba society is patriarchal in nature, and as a result, it is structured in favour of men taking initiative in the marriage process. Thus, it is the man who formalizes his desire to proceed to the next level of courtship by visiting the house of the bride-to-be through the middle man (alarina). After the alarina might have established the relationship between the two families, the husband to be pays the (Isihun) fee. Then the family members of the groom to be institutionalize the marriage by first going to ask for the hand of the bride to be. The relations of the bride plan for the engagement ceremony which creates a bond between the two families. 
International Journal of Applied Linguistics \& English Literature

ISSN 2200-3592 (Print), ISSN 2200-3452 (Online)

Vol. 1 No. 7; November 2012 [Special Issue on Applied Linguistics]

The meeting place for the potential couple is the evening market, (Oja ale). It is also the place for seeking spouses. During this period, it is a cultural obligation for mothers of young female adults to send their daughters on errands to the market. Often times, young females have wares to sell at the evening market. The female continues to go to the evening market until a serious prospect is secured. The genuineness of the potential spouse's claim of love is determined, when after many meetings at the evening market, the young man offers to go and visit the young female in her parent's home. Among the Yoruba, the etiquette regulating the would be couple's interaction demands that the groom avoids going to the girl's house. The determination to visit the potential bride at home is a final proof of readiness to engage in a serious relationship. However, before the suitor takes this important step, he should inform his father about his intentions. The father of the suitor then informs the eldest male member of the extended family, (Idile), who is known as the elderly father (Baba agba).

The suitor's father communicates the message to the eldest member of the lineage in symbolic language, "Elderly father, your son has seen a beautiful flower that he thinks he wants to pluck" (Omo yin ti ri ododo elewa ti o fe ja). The elderly relative then replies, "Can our family members pluck a flower from that family tree?" (Nje awon ebi wa le ja ododo lati iru igi bee?). The father of the suitor answers that from inquiries already made, members of their extended family can pluck flowers from the said tree. Then the elderly father gives his blessing by appointing a wife of the family to serve as the go-between (Alarena).

The choice of a much respected wife as the go-between has complex sociological implications. As an affine member of the lineage, she has the immunity of an outsider with a proven record of excellent service as a wife and a role model for new wives of members of the lineage. The Yoruba, who are very secretive and status-conscious, would find it offensive for a family member of the husband to take on this sensitive job of finding background information about the family history of the prospective wife. Because the go-between is an outsider acting on behalf of the male descendants of family, the culture accords her the immunity to carry out her assigned duty as a neutral party.

Yet the main condition for her selection is her intense loyalty to the extended family into which she married. The office of the go-between is also a mechanism for the smooth integration of the wife-to-be into her family of marriage. If things work out, the new wife is not completely alone in her new family. She has a collaborator already in the person of the go-between. The go-between tries to discover information that will assist the elders of the suitor's family in deciding whether the spouse would be a good companion for their son and a good resource in the extended family. If the go-between finds out that members of the spouse's family are lazy, that their womenfolk are stubborn and incorrigible in their marital homes, or if men in the extended family of the spouse are notorious debtors or have been known to have debilitating diseases, this information will be passed on to the elders, who will subsequently bring pressure to bear on their son to discontinue the relationship.

If inquiries reveal that the spouse's family members have a reputation for hard work, respect for elders, a great sense of nurture and motivation to induce their children to excel, every effort will be made to move the courtship to the next step in the process. The male elders direct the father of the suitor to find out from the oracle the future prospects of the union. The Yoruba are pragmatic. They want to know ahead of time whether the endeavour is worth the effort. The oracle is an instrumental use of symbolic inquiry to fathom the profitability of a future enterprise.

A married man in the traditional Yoruba family setting lives with his parents and siblings still. The typical traditional Yoruba compound contains a large patriarchal extended family. The head of the family is usually the most senior male member, and the men are normally polygamous, with each wife having a separate room. Therefore, the new bride relates with the whole extended family members every day and she addresses them honorifically, even the youngest of them. Among the Yoruba tribe in West Africa, brides are not expected to call their in-laws by names.

Culturally, a new bride is regarded by her husband's family members as the newest and youngest therefore, she must duly accord them some respect. In order not to be disrespectful, she coins names for them according to her perception of their physical characteristics and behavioural disposition; such names are either complimentary or derogatory depending on her personal relationships with individual in-laws.

Respect is however expected to be reciprocated by the in-laws. If the bride finds any of her in-laws offensive, she may not quarrel with them openly, instead of quarrelling; she reacts through the nicknames she coins to call such an in-law. Thus, such name could be complimentary or derogatory. 
International Journal of Applied Linguistics \& English Literature

ISSN 2200-3592 (Print), ISSN 2200-3452 (Online)

Vol. 1 No. 7; November 2012 [Special Issue on Applied Linguistics]

\section{Theoretical Framework}

The study adapts Halliday's theory of context. He believes that knowledge is transmitted in social contexts, through relationships, such as relationships existing between parent and child, or teacher and pupil which are distinguished and measured through the existing value systems and ideology of the culture. And the words that are exchanged in these contexts get their meaning from activities in which they are embedded, which again are social activities with social agencies and goals. Halliday is of the opinion that language study should be approached from a social perspective and insists that the study of words or utterances and even whole chunks of discourse alone is inadequate for proper understanding of such words. Hence, he subscribes that meanings are made in the context of the social situation in which such words are employed and meanings are given by members of social groups in the on-going activities in which they take part. Sinclair and Coulthard (1992) in the same vein note that a consideration of situation is essential for classifying items based on the non-linguistic environment, or the context of culture and situation.

Halliday, along with many other linguists (as well as anthropologists, sociologists, and philosophers of language), who approach language study from a social perspective, all insist that the study of words and utterances alone, even whole chunks of discourse without context is inadequate for the understanding of them. They can only be understood in context--the physical setting, participants, and other semiotic forms such as gestures, gaze, and so on. As Halliday (1971) has pointed out, it is meaningless to consider the linguistic "code" and linguistic "behaviour" as two separate things. A semantically based functional description of language must take account of the fact that code and behaviour are part and parcel of the same thing, the comprehension and interpretation of the social order. The social context of the linguistic code is the culture - seen as a network of information systems, and the social context of language behaviour is the situation in which socio-cultural meanings are replaced through the linguistic code. In Halliday's words:

"Context is in this kind of model a construct of cultural meanings, realised functionally in the form of acts of meaning in the various semiotic modes, of which language is one. The on-going processes of linguistic choice, whereby a speaker is selecting within the resources of the linguistic system, are effectively cultural choices, and acts of meaning are cultural acts" (p 165).

The present study therefore, subjects the twelve randomly selected nicknames to a socio-semantic analysis adopting Halliday's theory of context by bringing out meanings based on cultural understandings of the Yoruba people.

\section{Methodology}

Data for the study was collected from both primary and secondary sources, through observation and interaction with new brides and relatively old married women. As a native speaker of Yoruba language and a married woman in the Yoruba culture, I was able to identify some nicknames and some others were identified from books. However, nicknames that are commonly used for both male and female in-laws were identified and twelve of them were randomly selected from a list of twenty five nicknames for the study. An oral interview revealed that meanings of such nicknames used connote social as well as cultural implications.

The following nicknames are analyzed to show their socio-semantic import:

Ayiluko

It means a woman that wriggles and rolls all over her husband. In other words, it means a short robust woman who wriggles her backside when she walks. A bride might decide to nickname her sister-in-law 'Ayiluko' based on her physical appearance as described, but it could also be as a result of the bride indirectly telling a bossy sister-in-law to go look for her own husband and leave the bride and her husband alone. This nickname can be used derogatorily or as a compliment. Gesture plays a great role here as it reveals the intention of the bride.

Opelenge

This denotes a very slender or extremely slim and tall lady. The bride might lovingly call her fragile sister-in-law 'Opelenge' and so dotes on her. But, if on the other hand the sister-in-law is hostile to her, she calls her 'Opelenge' in order to ridicule her. Ordinarily, the Yoruba appreciate plump and robust ladies. The bride's gesture as she uses the nicknames plays a significant role in understanding her original intention.

\section{Ejiwumi}

'Eji' means diastem while 'wumi' denotes 'I love'. So, the nickname means 'I love your diastem or the gap in your teeth'. This is her way of appreciating the in-laws' physical attributes, especially the gap in the teeth.

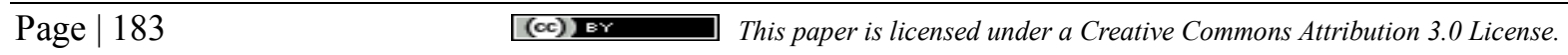




\section{International Journal of Applied Linguistics \& English Literature \\ ISSN 2200-3592 (Print), ISSN 2200-3452 (Online)}

Vol. 1 No. 7; November 2012 [Special Issue on Applied Linguistics]

However, some gaps could be so wide as to cause some embarrassment to the person, more so for a lady. If the bride is not in good terms with such an in-law, she uses such a nickname with no restraint to spite the in-law.

Agoro

This describes a very tall and lanky man. As much as this nickname is descriptive, it is derogatory because it is an indirect way of abusing the tall person.

Aguntasoolo

Aguntasoolo (Agun-to-aso-o-lo) denotes tall, straight, fashionable and presentable and it is used as a compliment for a tall in-law.

Akowe

This literally means "a person that writes" and connotes an educated and enlightened person. Such a nickname is used a male in-law who is actually in school.

Arope

'Arope' stands for a very short man. It is derogatory in that originally, it describes particular specie of dogs.

Akuruyejo

This nickname means short but very comely and skilful at dancing. It is a compliment for a short in-law if a cordial relationship exists between a bride and such an in-law.

\section{Adumaadan}

By denotation, this nickname stands for a black and shiny person. It is a complimentary remark from the bride to a very dark complexioned in-law.

\section{Agunlejika}

The Yoruba believe that a man with well-shaped square, broad shoulders is very handsome. 'Agun' connotes 'precision' while 'le ejika' means 'at the shoulders'. It is a compliment from the bride to a responsible, hardworking and caring male in-law.

Awelewa

This nickname typifies an extremely beautiful lady. 'ewa' means beauty 'awelewa' depicts multiple beauty. A bride uses such a nickname to lovingly appreciate a very beautiful and kind sister-in-law.

Idi Ileke

Among the Yoruba, 'idi' denotes buttocks and 'ileke' stands for beads, hence, this nickname means 'beaded buttocks'. A bride employs this name to compliment the sister-in-law and her family. It should be noted here that beads are a symbol of riches, royalty and honour among the Yoruba hence, an adoption of this nickname for a sister in-law.

\section{Statistical Analysis}

Table 1 provides information on Indication of classes (complimentary/derogatory) of the nicknames studied.

Table 1. Indication of classes (complimentary/derogatory) of the nicknames studied

\begin{tabular}{|l|l|l|}
\hline Nicknames & Complimentary & Derogatory \\
\hline Ayiluko & + & + \\
\hline Opelenge & + & + \\
\hline Ejiwumi & + & - \\
\hline Agoro & + & - \\
\hline Akowe & + & - \\
\hline Arope & - & + \\
\hline Adumaadan & + & - \\
\hline Akuruyejo & + & - \\
\hline Agunlejika & + & - \\
\hline Awelewa & + & - \\
\hline Idi ileke & + & - \\
\hline Aguntasoolo & + & - \\
\hline
\end{tabular}


International Journal of Applied Linguistics \& English Literature

ISSN 2200-3592 (Print), ISSN 2200-3452 (Online)

Vol. 1 No. 7; November 2012 [Special Issue on Applied Linguistics]

From Table 1 above, three nicknames Ayiluko, Opelenge and Ejiwunmi assume the dual functions of complimentary and insulting categories. While two nicknames, Agoro and Arope are derogatory nicknames, the remaining seven nicknames on the table are all compliments.

Table 2. Table indicating frequency and percentage of the nicknames studied

\begin{tabular}{lll}
\hline Nicknames & Frequency & Percentage \\
\hline Complimentary & 7 & 58 \\
\hline Derogatory & 2 & 17 \\
\hline Complimentary/ Derogatory & 3 & 25 \\
\hline Total & 12 & 100 \\
\hline
\end{tabular}

Consequently, Table 2 indicates the frequency and percentage of the nicknames studied. Table shows that the complimentary column has seven frequency counts (58\%) and derogatory has two (17\%). In the dual category of both complimentary and derogatory, there are three frequency counts $(25 \%)$. It is interesting to note that some nicknames could be used in both ways; usage is established through the bride's gesture while using the nicknames.

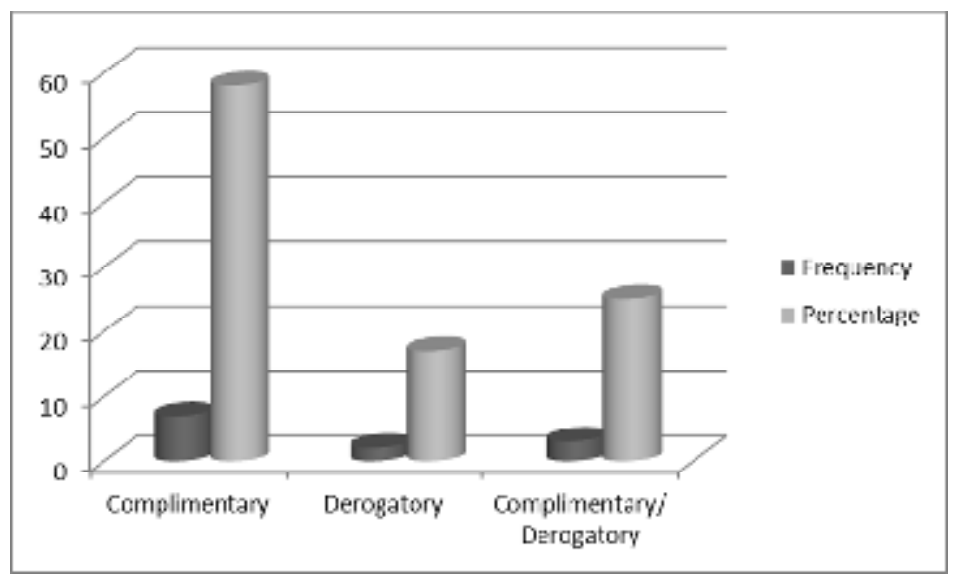

Figure 1. A Bar-chart illustrating frequency and percentage

Figure 1 is a pictorial illustration capturing the summary of findings of the study succinctly.

Results from the socio-semantic analysis of nicknames used by Yoruba brides for their in-laws reveal a rich and fascinating culture through the coining of names. One can easily identify in-laws' personality, either physically or behavioural through their nicknames. The fact that brides are forbidden to call their in-laws by first names underscores the aspect of respect among the Yoruba people. Respect for elders and in-laws is held in high esteem and to some extent, it determines the quality of a person's character. To this end, societal values, for instance greetings, are maintained relatively. It is interesting to note however that modernisation has caught up with this beautiful culture as modern brides to be do not observe this any longer. No wonder the high rate of divorce among modern youths. Surprisingly, such high rates of divorce are not seen among the traditionally inclined youth. This indicates that the psychological effect of this practice on the male ego is highly positive as it readily endears the bride to the groom and in-laws.

\section{Conclusion}

In conclusion, the socio-semantic analysis of these nicknames depicts the richness of the Yoruba culture and the importance attached to marriage and relationships. Generally, Yoruba people are appreciative of beauty, they are respectful and honourable; these attributes reflect in their daily activities and most importantly, in their relationships with loved ones. In Yoruba land, the naming process suggests that the family is the social unit through which an individual is identified because his/her name has a clear specificity. This is in sharp contrast to the rather anonymity of English names. Dean Shanna corroborates this view in stating that "family is the Yoruba culture's theme when it comes to matrimony. Values are passed on by example. Traditions are respected, and most importantly, family is the key". 
International Journal of Applied Linguistics \& English Literature

ISSN 2200-3592 (Print), ISSN 2200-3452 (Online)

Vol. 1 No. 7; November 2012 [Special Issue on Applied Linguistics]

\section{References}

Babatunde, E. D. (1992). Culture, Religion and the Self: A Critical Study of Bini and Yoruba Value Systems in Change. Lewiston, NY: Edwin Mellen Press.

Babatunde, E. D. \& Zeitlin, M. F. (1995). "The Yoruba Family: Kinship, Socialization and Child Development. In. Zeitlin, M. F.; Megawangi, R.; Kramer, E. M.; Colletta, N. D; Babatunde, E. D; \& D. Garman (Eds). Strengthening the Family: Implications for Development. Tokyo: United Nations University Press.

Dean, S. Yoruba Marriage. [Online] Available: www.theearthcenter.com/templates. 2012

Forde, D. (1951). The Yoruba-Speaking peoples of South Western Nigeria. London: International African Institute.

Halliday M.A.K. (1971). Language in a Social Perspective: The Context of Language Educational Review. University of Birmingham. 23.3. pp.165-188.

Sinclair, J. \& Coulthard, M. (1992). Toward an analysis of discourse. In Coulthard, M. (ed.) 1992. Advances in Spoken Discourse Analysis. 1-34. Routledge.

Sowande, F. (1967). The Mind of a Nation: The Yoruba Child. Ibadan, Nigeria. [Online] Available: cocojams17@yahoo.com.20012. 